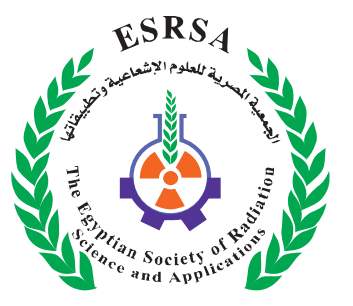

\title{
Effect of Chromium and Selenium-E on Progesterone and Estradiol-17ß Levels during Reproductive Cycle of Baladi Female Goats under Egyptian Conditions
}

El-Sayed $^{1}$ A. I. M., Farghaly ${ }^{2}$ H. A. M., El-Zaher ${ }^{2}$ H. M. and Eid ${ }^{2}$ S. Y.

Received: 14/01/2018

Accepted: 13/02/2018

E.mail:sherifyousif00@gmail.com

KEYWORDS

Chromium,

Selenium-E, Heat

Stress, Progesterone,

Estradiol-17p, Goats.

\section{ABSTRACT}

The effect of chromium and selenium with vitamin $\mathrm{E}$ on progesterone $\left(\mathrm{P}_{4}\right)$ and estradiol-17 $\beta\left(\mathrm{E}_{2}\right)$ levels of Baladi female goats was the objective of this study as new techniques for improving the reproductive performance of Egyptian goats. Seventy-two of mature Baladi does were used through two conditions of mild and hot climates (36 animals / season). The animals were randomly divided into three equal groups, the $1^{\text {st }}$ is the control group, the $2^{\text {nd }}$ group was supplemented by chromium in capsules and the $3^{\text {rd }}$ group was intramuscularly injected twice a week with $2 \mathrm{ml}$ VITESELEN $\mathbb{R},(0.5 \mathrm{mg}$ sclenium and 10.7 IU vitamin E, Se-E). Serum hormones levels were assessed in the three experimental goats at the estrous, pregnancy and postpartum periods. The results showed that $\mathrm{P}_{4}$ levels during estrous cycle and mid-pregnancy periods were significantly higher in mild climate than in hot climate while opposite trend was found during early and late pregnancy as well as postpartum period. $E_{2}$ levels during postpartum period were significantly higher in hot climate than in mild while during estrous cycle no significant differences in E2 levels due to season. Chromium showed significant $(\mathrm{P}<0.05)$ increase in $\mathrm{P}_{4}$ levels in goats during each of estrous cycle and pregnancy periods and showed significant decrease in $\mathrm{P}_{4}$ levels in goats during postpartum period as compared with control. Selenium-E significantly increased the concentration of $\mathrm{P}_{4}$ in goats during each of the luteal phase of estrous cycle, pregnancy and at $30^{\text {th }}$ day postpartum periods as compared with control. The opposite trend was found at $15^{\text {th }}$ and $45^{\text {th }}$ days postpartum. No significant difference

\footnotetext{
Department of Animal Production, Faculty of Agriculture, Benha University, Benha, Egypt, P.O.13736.

2. Department of Biological Applications, Radioisotopes Applications Division, Nuclear Research Center, Atomic Energy Authority, Inshas, Cairo, Egypt, P.O.13759.
} 
in P4 due to Selenium-E during follicular phase of estrous cycle. Chromium showed significant decrease in $\mathrm{E}_{2}$ levels in goats on $15^{\text {th }}$ and $45^{\text {th }}$ days postpartum period while no significant differences in E2 levels due to chromium treatment during estrous cycle and $30^{\text {th }}$ day of postpartum period. Selenium-E increased significantly $E_{2}$ level during estrous cycle and postpartum periods.

\section{INTRODUCTION}

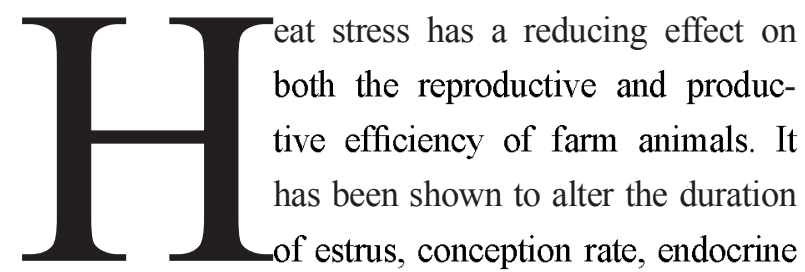
status, follicular growth and development; early embryonic development and fetal growth (Jordan, 2003). The breeding season of goats begins when the photoperiod become shorter, depending on daylight, breed and diet (Chemineau et al. 1999). In Egypt, as the days begin to shorten in the late summer and early autumn, a regular estrus cycle is initiated; and in late winter and early spring when the days are lengthening; partial anestrus occurs. Egyptian Baladi goats shows normal breeding season at mid-summer and continue through the autumn season. However, a considerable percentage of Baladi goats exhibit estrus signs during out-of-season period (32\%) (EITarabany et al., 2017 \& 2018).

In goats, heat stress reduced plasma concentrations of estradiol and lowered follicular estradiol concentration, LH receptor level, delayed ovulation (Ozawa et al.,2005), altered follicular growth (Roth et al.,2000 and Hansen, 2009), and disrupt the development and function of the oocytes (AL-Katanani et al,2002; Sartori et al.,2002 and Hansen, 2009). Roth et al. (2000) suggested that early atresia in medium sized follicles because of heat stress could be associated with low estradiol production by granulosa cells and increased progesterone concentrations in the fol- licular fluid of heat-stressed cows. In addition, heat stress can cause increased cortisol secretion (Wise et al., 1988 and Elvinger et al., 1992), and АCTH has been reported to block estradiol-induced sexual behavior (Hein and Allrich, 1992). Emesih et al. (1995) reported that pregnant doe goats exposed to heat stress showed higher plasma progesterone concentrations than in those maintained at moderate ambient temperature.

Studying chromium importance as an essential element for livestock animals intensively started in 1990s (Pechova and Pavlata 2007). Garcia et al. (1997) have studied the effect of Cr-picolinate supplementation on sensitivity of tissues to insulin, ov ulation rate, and progesterone and oxytocin secretion; Cr supplementation had a positive effect on the ovulation rate but progesterone concentrations remained unchanged. A positive effect of $\mathrm{Cr}$ supplementation on the insemination index, interval and service period has been established (Bonomi et al., 1997 and Pechova et al., 2003). Selenium, an essential part of the antioxidant defense system, plays an important role in the growth and health of humans and livestock through its participation in several important enzymes and enzyme reactions (Surai, 2006). Selenium deficiency has been related to reproductive failures in ruminants, and Vitamin-E is an important complementary factor (Buchanan-Smith et al., 1969).

The issues of reproduction in relation to $\mathrm{Cr}$ supplementation have been devoted relatively little attention, so this paper aims to find out the effect of chromium and selenium-E administration on progesterone and estradiol-17 $\beta$ concentrations during estrous cycle, pregnancy and postpartum periods of Baladi doe goats under Egyptian conditions.

\section{MATERIALS AND METHODS}

Animals and feeding:

This experiment was carried out in Goats Experi- 
mental Farm, Nuclear Research Center, Atomic Energy Authority, Inshas; (latitude $31^{\circ} 12^{\prime} \mathrm{N}$ to $22^{\circ} 2^{\prime} \mathrm{N}$, longitude $25^{\circ} 53$ ' E to $35^{\circ} 53^{\prime} \mathrm{E}$ ). The experimental animals were healthy and clinically free of external and internal parasites and were fed basal ration of concentrate feed mixture (CFM) according to the allowances of NRC (2007) of goats. The CFM composed of $37.4 \%$ wheat bran, $27 \%$ yellow corn, $12.5 \%$ soybean meal, $10.0 \%$ undecorticated cottonseed cake, $5 \%$ rice bran, $4 \%$ sugarcane molasses, $3 \%$ limestone, $1 \%$ sodium chloride and 0.1 vitamin and minerals premix. Feed mixture was offered once daily at 9:00 a.m., based on $3.5 \%$ of body weight. Barseem hay was offered ad libitum. Fresh drinking water was available at all time.

\section{Animal housing:}

All experimental animals were kept in semi-open pens throughout the experimental period. These pens were provided with enough shade and ventilation in summer and protection from rain in winter. The does were allowed to graze five hours daily at least.

\section{Experimental design:}

Seventy-two mature female goats ( 36 animals/ season) aged 2-3 years old with average body weigh $25 \pm$ $1.5 \mathrm{~kg}$ were randomly divided into three equal groups. Animals in the $1^{\text {st }}$ group were kept as control, the $2^{\text {nd }}$ group was supplemented by chromium (chromium chloride trivalent), $0.8 \mathrm{mg} / \mathrm{hcad} /$ day as capsules (Williams et al., 1994) and the $3^{\text {rd }}$ group was intramuscularly injected with $2 \mathrm{ml}$ VITESELEN $\mathbb{R}$, contained 0.5 $\mathrm{mg}$ selenium and $10.7 \mathrm{IU}$ vitamin $\mathrm{E} /$ head/day.

\section{Estrus synchronization and blood sampling:}

All groups received $10 \mathrm{ml}$ of PGF2 $\alpha$ (lutalyse) in double dose ( $5 \mathrm{mg} /$ dose, IM) at 11 day-intervals, followed by $500 \mathrm{IU}$ of hCG; then after 24 hours three fertile bucks (one buck for each group) were introduced to the does and allowed to be with does for two successive estrous cycles for estrous detection and natural mating. Blood samples were collected from the jugular vein in evacuated glass tubes, and kept at room temperature from 30 to $60 \mathrm{~min}$ for clotting, then centrifuged at 3000 $\mathrm{rpm}$ for $15 \mathrm{~min}$ to separate serum. After that serum was stored at $-20^{\circ} \mathrm{C}$ until analyzed. Samples were collected throughout different stages of estrous cycle, according to Fatet et al. (2011); monthly during pregnancy and every 15 -day up to 45 days postpartum.

\section{Ambient temperature, relative humidity and temperature humidity index:}

The ambient temperature and relative humidity were recorded daily from meteorological station of Atomic Energy Authority during the whole experimental period. The temperature humidity index (THI) was calculated during mild and hot climates according to Marai et al. (2000) as:

$$
\mathrm{THI}=\mathrm{db}{ }^{\circ} \mathrm{C}-\left[(0.31-0.31 \mathrm{RH}) \times\left(\mathrm{db}{ }^{\circ} \mathrm{C}-14.4\right)\right]
$$

where, $\mathrm{THI}=$ temperature humidity index, $\mathrm{db}{ }^{\circ} \mathrm{C}=\mathrm{dry}$ bulb temperature in Celsius and $\mathrm{RH}=$ relative humidity $100 \div$. A value for THI $<22.2$ was considered remarkably an absence of heat stress, while the values from 22.2 to 23.3 referred to moderate (mild) heat stress, 23.3 to $<25.6$ referred to severe heat stress and $>25.6$ referred to very severe heat stress.

Table (1) : Mean Values of THI during the experimental period.

\begin{tabular}{|c|c|c|c|c|c|c|}
\hline \multirow{2}{*}{ Climate } & \multicolumn{2}{|c|}{ Ambient temperature } & \multicolumn{2}{c|}{ Relative humidity values \% } & \multicolumn{2}{c|}{ THI } \\
\cline { 2 - 7 } & Max & Mini & Max & Mini & Max & Mini \\
\hline Mild & 23.47 & 14.24 & 80.01 & 27.44 & 22.9 & 13.9 \\
\hline Hot & 34.15 & 23.28 & 77.91 & 20.30 & 32.8 & 23.5 \\
\hline
\end{tabular}

Mild= October, November, December, January, February and March; Hot= May, June, July, Augustus, September, October 


\section{Progesterone and estradiol-17ß $\left(P_{4}\right.$ and $\left.E_{2}\right)$ :}

Serum P4 $(\mathrm{ng} / \mathrm{ml})$ and $\mathrm{E} 2-17 \beta(\mathrm{Pg} / \mathrm{ml})$ concentrations were determined using Coat-A-count $\mathrm{I}^{125}$ RIA kits obtained from Immunotech a Beckman Coulter Company, Czech Republic.

\section{Statistical analysis:}

Data were expressed as mean $\pm \mathrm{SE}$. Data were analyzed statistically by GLM procedure of the SAS program (SAS, 1998) according this equation:

$\mathrm{Y}_{\mathrm{ijk}}=\mu+\mathrm{S}_{\mathrm{i}}+\mathrm{T}_{\mathrm{j}}+(\mathrm{ST})_{\mathrm{ij}}+\mathrm{e}_{\mathrm{ijk}}$ where, $\mathrm{Y}_{\mathrm{ijk}}=$ the dependent variables estimated, $\mu=$ Overall mean, $S_{i}=$ the effect of $i^{\text {th }}$ season $(1=$ mild and $2=h o t), T_{j}=$ the effect of $j^{\text {th }}$ treatment ( $1=$ control, $2=$ chromium and $3=$ selenium-E), $\mathrm{ST}_{\mathrm{ij}}=$ the effect of interaction between season and treatment and $\mathrm{e}_{\mathrm{ijk}}=$ random error.

Duncan's Multiple Range test was used to detect the differences among means of the experimental groups (Duncan, 1955).

\section{RESULTS}

\section{Effect of climate conditions and treatments on progesterone $\left(P_{4}\right)$ levels.}

Inspection the effect of treatments on $\mathbf{P}_{4}$ concentrations, it is noticeable that $\mathrm{P} 4$ levels were significantly higher in mild climate than in hot with the highest value $19.53 \mathrm{ng} / \mathrm{ml}$ at luteal phase in mild climate versus11.21 ng/ml in hot one. Cr supplementation resulted in significant increase in $(\mathrm{P}<0.05)$ $\mathrm{P} 4$ level during estrous cycle compared with other groups. The response to $\mathrm{Cr}$ treatment found to be a higher magnitude $(25.39 \mathrm{ng} / \mathrm{ml})$ during luteal phase, followed by Se-E (13.11ng/ml). Se-E does have higher $(\mathrm{P}<0.05) \mathrm{P} 4$ concentration at luteal phase than control, with values of $11.79 \mathrm{ng} / \mathrm{ml} v s .6 .57 \mathrm{ng} /$ $\mathrm{ml}$, respectively (Table 2 ).

Under mild climate conditions, treated groups were higher $(\mathrm{P}<0.05)$ in $\mathrm{P} 4$ than control during estrous cycle. Does of $\mathrm{Cr}$ group had the highest in $\mathrm{P} 4$ levels $(40.40 \mathrm{ng} / \mathrm{ml})$ at luteal phase, followed by Se-E $(13.86 \mathrm{ng} / \mathrm{ml})$. On the other side, under hot climate, $\mathrm{Cr}$ or Se-E supplementations had no significant effect on P4 concentrations as compared to control at two the phases of estrous cycle. Results obtained revealed that serum $\mathbf{P}_{4}$ levels significantly $(\mathrm{P}<0.05)$ affected by climate, treatment and their interactions during pregnancy (Table 2).

Treating does by $\mathrm{Cr}$ or Se-E increased $(\mathrm{P}<0.05)$ P4 concentrations during early, mid- and late-pregnancy more than control. Cr treatment almost had P4 concentrations higher than Se-E, the highest value of $45.55 \mathrm{ng} / \mathrm{ml}$ was at mid-pregnancy, followed by 31.22 $\mathrm{ng} / \mathrm{ml}$ for Se-E versus $21.72 \mathrm{ng} / \mathrm{ml}$ for control. During early and late-pregnancy, there was no significant difference between $\mathrm{Cr}$ and Se-E groups in P4 levels. Marked increase in $\mathrm{P} 4$ concentrations was found due to $\mathrm{Cr}$ and $\mathrm{Se}-\mathrm{E}$ treatments with mean values of 62.95 and $39.61 \mathrm{ng} / \mathrm{ml}$, respectively, at mid-pregnancy of mild climate. The significant effect due to $\mathrm{Cr}$ or Se-E treatments under hot climate conditions was an increase $(21.17 \mathrm{ng} / \mathrm{ml}, \mathrm{P}<0.05)$ at carly pregnancy and a decrease $(21.24 \mathrm{ng} / \mathrm{ml})$ at late pregnancy comparing with control, otherwise the treatments did not show significant differences in P4 levels during pregnancy period (Table 2).

During postpartum period $\mathrm{Cr}$ treatment showed significant decrease $(\mathrm{P}<0.05)$ in $\mathrm{P} 4$ concentration on $15^{\text {th }}$ and $54^{\text {th }}$ as compared with control especially under hot climate conditions. On the other side, Se-E resulted in an increase $(5.05 \mathrm{ng} / \mathrm{ml} ; \mathrm{P}<0.05)$ in $\mathrm{P} 4$ concentration on day-30 PP comparing with other groups. This increase was clearly shown during hot climate with mean values $9.36 \mathrm{ng} / \mathrm{ml}$ vs. 1.74 and $1.17 \mathrm{ng} / \mathrm{ml}$ for Se-E, $\mathrm{Cr}$ and control, respectively. Otherwise, both treatments were lower than control (Table 2). 
Table (2) : Effect of chromium and selenium-E on progesterone levels ( $\mathrm{g} / \mathrm{ml}$; means $\pm S E)$ during estrous, pregnancy and postpartum periods of Baladi does.

\begin{tabular}{|c|c|c|c|c|c|c|c|c|}
\hline \multirow{3}{*}{ Items } & \multicolumn{8}{|c|}{ Progesterone (ng/ml; means $\pm \mathrm{SE})$} \\
\hline & \multicolumn{2}{|c|}{ Estrous cycle } & \multicolumn{3}{|c|}{ Pregnancy period } & \multicolumn{3}{|c|}{ Postpartum period } \\
\hline & $\begin{array}{c}\text { Follicular } \\
\text { Phase }\end{array}$ & $\begin{array}{l}\text { Luteal } \\
\text { phase }\end{array}$ & Early & Mid & Late & $\begin{array}{c}\text { 15-day } \\
\text { PP }\end{array}$ & $\begin{array}{c}\text { 30-day } \\
\text { PP }\end{array}$ & $\begin{array}{c}\text { 45-day } \\
\text { PP }\end{array}$ \\
\hline \multicolumn{9}{|c|}{ Climate condition (s) } \\
\hline Mild & $2.10 \pm 0.19$ & $\begin{array}{l}19.53 \\
\pm 2.71\end{array}$ & $9.72 \pm 0.6$ & $\begin{array}{l}39.24 \\
\pm 4.41\end{array}$ & $\begin{array}{c}22.22 \\
\pm 1.9\end{array}$ & $\begin{array}{c}0.95 \\
\pm 0.04\end{array}$ & $\begin{array}{c}0.61 \\
\pm 0.02\end{array}$ & $\begin{array}{c}0.38 \\
\pm 0.02\end{array}$ \\
\hline Hot & $1.62 \pm 0.05$ & $\begin{array}{l}11.21 \\
\pm 0.56\end{array}$ & $\begin{array}{l}18.88 \\
\pm 0.8\end{array}$ & $\begin{array}{l}26.42 \\
\pm 1.5\end{array}$ & $\begin{array}{c}25.17 \\
\pm 1.1\end{array}$ & $\begin{array}{c}2.15 \\
\pm 0.12\end{array}$ & $\begin{array}{c}4.42 \\
\pm 0.62\end{array}$ & $\begin{array}{c}1.87 \\
\pm 0.16\end{array}$ \\
\hline$P$ - value & 0.001 & 0.0001 & 0.0001 & 0.0001 & 0.069 & 0.0001 & 0.0001 & 0.0001 \\
\hline \multicolumn{9}{|c|}{ Treatments } \\
\hline Control & $\begin{array}{l}1.66^{\mathrm{B}} \\
\pm 0.09\end{array}$ & $\begin{array}{l}7.60^{\mathrm{C}} \\
\pm 0.75\end{array}$ & $\begin{array}{c}12.02^{\mathrm{B}} \\
\pm 1.2\end{array}$ & $\begin{array}{c}21.72^{\mathrm{C}} \\
\pm 1.6\end{array}$ & $\begin{array}{c}18.56^{\mathrm{B}} \\
\pm 2.2\end{array}$ & $\begin{array}{l}1.77^{\mathrm{A}} \\
\pm 0.19\end{array}$ & $\begin{array}{l}1.35^{\mathrm{B}} \\
\pm 0.17\end{array}$ & $\begin{array}{l}1.85^{\mathrm{A}} \\
\pm 0.29\end{array}$ \\
\hline $\mathrm{Cr}$ & $\begin{array}{l}2.39^{\mathrm{A}} \\
\pm 0.30\end{array}$ & $\begin{array}{l}25.39^{A} \\
\pm 3.40\end{array}$ & $\begin{array}{c}15.09^{\mathrm{A}} \\
\pm 1.5\end{array}$ & $\begin{array}{c}45.55^{\mathrm{A}} \\
\pm 6.1\end{array}$ & $\begin{array}{c}27.09^{\mathrm{A}} \\
\pm 1.5\end{array}$ & $\begin{array}{l}1.27^{\mathrm{C}} \\
\pm 0.07\end{array}$ & $\begin{array}{l}1.14^{\mathrm{B}} \\
\pm 0.13\end{array}$ & $\begin{array}{l}0.73^{\mathrm{C}} \\
\pm 0.08\end{array}$ \\
\hline Se-E & $\begin{array}{l}1.53^{\mathrm{B}} \\
\pm 0.07\end{array}$ & $\begin{array}{l}13.11^{\mathrm{B}} \\
\pm 0.68\end{array}$ & $\begin{array}{c}15.80^{\mathrm{A}} \\
\pm 1.0\end{array}$ & $\begin{array}{c}31.22^{\mathrm{B}} \\
\pm 1.9\end{array}$ & $\begin{array}{c}25.43^{\mathrm{A}} \\
\pm 1.6\end{array}$ & $\begin{array}{l}1.61^{\mathrm{B}} \\
\pm 0.17\end{array}$ & $\begin{array}{l}5.05^{\mathrm{A}} \\
\pm 0.95\end{array}$ & $\begin{array}{l}0.79^{\mathrm{B}} \\
\pm 0.1\end{array}$ \\
\hline$P$-value & 0.0001 & 0.0001 & 0.003 & 0.0001 & 0.0001 & 0.0001 & 0.0001 & 0.0001 \\
\hline \multicolumn{9}{|c|}{ Climate $x$ Treatments interactions } \\
\hline \multicolumn{9}{|c|}{ Mild } \\
\hline Control & $1.65^{\mathrm{b}} \pm 0.18$ & $\begin{array}{l}4.32^{c} \\
\pm 0.06\end{array}$ & $\begin{array}{l}7.01^{\mathrm{d}} \\
\pm 0.3\end{array}$ & $\begin{array}{c}15.15^{\mathrm{d}} \\
\pm 0.2\end{array}$ & $\begin{array}{l}9.76^{\mathrm{c}} \\
\pm 1.3\end{array}$ & $\begin{array}{l}0.88^{\mathrm{d}} \\
\pm 0.05\end{array}$ & $\begin{array}{l}0.53^{\mathrm{c}} \\
\pm 0.03\end{array}$ & $\begin{array}{c}0.46^{\mathrm{d}} \\
\pm 0.016\end{array}$ \\
\hline $\mathrm{Cr}$ & $3.35^{\mathrm{a}} \pm 0.33$ & $\begin{array}{l}40.40^{\mathrm{a}} \\
\pm 2.49\end{array}$ & $\begin{array}{l}9.00^{\mathrm{d}} \\
\pm 0.5\end{array}$ & $\begin{array}{c}62.95^{\mathrm{a}} \\
\pm 8.9\end{array}$ & $\begin{array}{c}27.29^{\mathrm{a}} \\
\pm 2.8\end{array}$ & $\begin{array}{l}1.16^{\mathrm{c}} \\
\pm 0.08\end{array}$ & $\begin{array}{l}0.55^{\mathrm{c}} \\
\pm 0.02\end{array}$ & $\begin{array}{c}0.33^{\mathrm{e}} \\
\pm 0.012\end{array}$ \\
\hline Se-E & $1.30^{\mathrm{b}} \pm 0.01$ & $\begin{array}{l}13.86^{\mathrm{b}} \\
\pm 0.58\end{array}$ & $\begin{array}{c}13.16^{\mathrm{c}} \\
\pm 1.3\end{array}$ & $\begin{array}{c}39.61^{\mathrm{b}} \\
\pm 1.5\end{array}$ & $\begin{array}{c}29.63^{\mathrm{a}} \\
\pm 2.4\end{array}$ & $\begin{array}{l}0.80^{\mathrm{d}} \\
\pm 0.02\end{array}$ & $\begin{array}{l}0.75^{\mathrm{c}} \\
\pm 0.04\end{array}$ & $\begin{array}{l}0.33^{\mathrm{e}} \\
\pm 0.01\end{array}$ \\
\hline \multicolumn{9}{|c|}{ Hot } \\
\hline Control & $1.66^{\mathrm{b}} \pm 0.10$ & $\begin{array}{l}10.89^{b} \\
\pm 0.63\end{array}$ & $\begin{array}{c}17.03^{\mathrm{b}} \\
\pm 1.3\end{array}$ & $\begin{array}{c}28.29^{\mathrm{bc}} \\
\pm 1.5\end{array}$ & $\begin{array}{c}27.36^{\mathrm{a}} \\
\pm 2.5\end{array}$ & $\begin{array}{l}2.65^{\mathrm{a}} \\
\pm 0.08\end{array}$ & $\begin{array}{l}2.17^{b} \\
\pm 0.10\end{array}$ & $\begin{array}{l}3.25^{\mathrm{a}} \\
\pm 0.01\end{array}$ \\
\hline $\mathrm{Cr}$ & $1.44^{\mathrm{b}} \pm 0.05$ & $\begin{array}{l}10.38^{\mathrm{b}} \\
\pm 0.94\end{array}$ & $\begin{array}{c}21.17^{\mathrm{a}} \\
\pm 1.6\end{array}$ & $\begin{array}{c}28.14^{\mathrm{bc}} \\
\pm 3.4\end{array}$ & $\begin{array}{c}26.91^{\mathrm{a}} \\
\pm 1.3\end{array}$ & $\begin{array}{l}1.38^{\mathrm{c}} \\
\pm 0.12\end{array}$ & $\begin{array}{l}1.74^{\mathrm{b}} \\
\pm 0.03\end{array}$ & $\begin{array}{l}1.14^{\mathrm{c}} \\
\pm 0.05\end{array}$ \\
\hline Se-E & $1.76^{\mathrm{b}} \pm 0.11$ & $\begin{array}{l}12.36^{\mathrm{b}} \\
\pm 1.22\end{array}$ & $\begin{array}{c}18.45^{\mathrm{ab}} \\
\pm 1.1\end{array}$ & $\begin{array}{c}22.82^{\mathrm{cd}} \\
\pm 0.7\end{array}$ & $\begin{array}{c}21.24^{\mathrm{b}} \\
\pm 1.1\end{array}$ & $\begin{array}{l}2.42^{\mathrm{b}} \\
\pm 0.08\end{array}$ & $\begin{array}{l}9.36^{\mathrm{a}} \\
\pm 0.63\end{array}$ & $\begin{array}{l}1.23^{\mathrm{b}} \\
\pm 0.02\end{array}$ \\
\hline$P$-value & 0.0001 & 0.0001 & 0.01 & 0.0001 & 0.0001 & 0.0001 & 0.0001 & 0.0001 \\
\hline
\end{tabular}

Means with different letters $(A, B$ and $C$ or $a, b, c, \ldots)$ in the same column are significantly different at $(P<0.05)$. 
Effect of climate conditions and treatments on estradiol-17ß $\left(E_{2}\right)$ levels.

It is obviously clear that, female goats treated with $\mathrm{Cr}$ or Se-E were higher in $\mathrm{E}_{2}-17 \beta$ concentrations more than control throughout follicular and luteal phases of estrous cycle, but the significant $(\mathrm{P}<0.05)$ increase was due to Se-E injection with mean value of $108.56 \mathrm{pg} / \mathrm{ml}$ during follicular phase (Table 3).
Under mild conditions, the significant $(\mathrm{P}<0.05)$ increase in $\mathrm{E}_{2}-17 \beta$ was 134.23 and $39.72 \mathrm{pg} / \mathrm{ml}$ during follicular and luteal phases, respectively due to Se-E supplementation. However, $\mathrm{Cr}$ increased $\mathrm{E}_{2}$ $17 \beta$ concentrations more than control throughout estrous cycle of mild or hot climate conditions. This increase was significant $(\mathrm{P}<0.05)$ at luteal phase of hot season with mean value of $31.52 \mathrm{pg} / \mathrm{ml}$ vs. 26.06 $\mathrm{pg} / \mathrm{ml}$ for control (Table 3 ).

Table (3) : Effect of chromium and selenium-E on Estradiol-17B levels ( $\mathrm{pg} / \mathrm{ml}$ means $=$ SE) during estrous and postpartum periods of Baladi does.

\begin{tabular}{|c|c|c|c|c|c|}
\hline \multirow{3}{*}{ Items } & \multicolumn{5}{|c|}{ Estradiol- $_{17 \beta}(\mathrm{pg} / \mathrm{ml} ;$ means $\pm \mathrm{SE})$} \\
\hline & \multicolumn{2}{|c|}{ Estrous cycle } & \multicolumn{3}{|c|}{ Postpartum period } \\
\hline & $\begin{array}{c}\text { Follicular } \\
\text { phase }\end{array}$ & $\begin{array}{l}\text { Luteal } \\
\text { phase }\end{array}$ & $\begin{array}{c}\text { 15-day } \\
\text { PP }\end{array}$ & $\begin{array}{c}\text { 30-day } \\
\text { PP }\end{array}$ & $\begin{array}{c}\text { 45-day } \\
\text { PP }\end{array}$ \\
\hline \multicolumn{6}{|c|}{ Climate condition (s) } \\
\hline Mild & $76.42 \pm 8.05$ & $24.17 \pm 2.14$ & $29.27 \pm 1.8$ & $38.73 \pm 3.30$ & $34.84 \pm 2.3$ \\
\hline Hot & $78.15 \pm 2.24$ & $28.22 \pm 0.77$ & $64.32 \pm 2.5$ & $47.04 \pm 2.30$ & $41.32 \pm 3.7$ \\
\hline$P$-value & 0.75 & 0.2 & 0.0001 & 0.005 & 0.029 \\
\hline \multicolumn{6}{|c|}{ Treatments } \\
\hline Control & $57.00^{\mathrm{B}} \pm 2.90$ & $20.74^{\mathrm{B}} \pm 1.44$ & $48.32^{\mathrm{B}} \pm 5.7$ & $35.45^{\mathrm{B}} \pm 2.9$ & $40.08^{\mathrm{B}} \pm 2.8$ \\
\hline $\mathrm{Cr}$ & $66.29^{\mathrm{B}} \pm 3.45$ & $24.45^{\mathrm{B}} \pm 1.56$ & $36.43^{\mathrm{C}} \pm 3.2$ & $34.90^{\mathrm{B}} \pm 3.3$ & $20.96^{\mathrm{C}} \pm 1.5$ \\
\hline Se-E & $108.56^{\mathrm{A}} \pm 8.03$ & $33.39^{\mathrm{A}} \pm 2.04$ & $55.65^{\mathrm{A}} \pm 3.4$ & $58.23^{\mathrm{A}} \pm 1.9$ & $53.19^{\mathrm{A}} \pm 3.4$ \\
\hline$P$-value & 0.0001 & 0.0001 & 0.0001 & 0.0001 & 0.0001 \\
\hline \multicolumn{6}{|c|}{ Climate $x$ Treatments interactions } \\
\hline \multicolumn{6}{|c|}{ Mild } \\
\hline Control & $41.23^{c} \pm 2.9$ & $15.43^{\mathrm{d}} \pm 1.28$ & $21.49^{c} \pm 1.3$ & $25.49^{\mathrm{d}} \pm 2.5$ & $30.26^{\mathrm{b}} \pm 0.23$ \\
\hline $\mathrm{Cr}$ & $53.80^{\circ} \pm 4.02$ & $17.38^{\mathrm{d}} \pm 0.24$ & $26.04^{c} \pm 3.3$ & $29.43^{\mathrm{d}} \pm 3.7$ & $21.05^{\mathrm{b}} \pm 1.12$ \\
\hline Se-E & $134.23^{\mathrm{a}} \pm 11.47$ & $39.72^{\mathrm{a}} \pm 2.98$ & $40.27^{b} \pm 1.4$ & $61.27^{\mathrm{a}} \pm 3.6$ & $53.22^{\mathrm{a}} \pm 1.1$ \\
\hline \multicolumn{6}{|c|}{ Hot } \\
\hline Control & $72.78^{b} \pm 4.47$ & $26.06^{\mathrm{c}} \pm 1.35$ & $75.14^{a} \pm 2.2$ & $45.41^{\mathrm{bc}} \pm 3.5$ & $49.91^{\mathrm{a}} \pm 0.41$ \\
\hline $\mathrm{Cr}$ & $78.77^{b} \pm 2.27$ & $31.52^{\mathrm{b}} \pm 1.01$ & $46.81^{b} \pm 3.4$ & $40.38^{\mathrm{c}} \pm 5.1$ & $20.88^{\mathrm{b}} \pm 2.8$ \\
\hline Se-E & $82.89^{\mathrm{b}} \pm 4.28$ & $27.07^{\mathrm{c}} \pm 1.11$ & $71.02^{\mathrm{a}} \pm 1.6$ & $55.32^{\mathrm{ab}} \pm 1.1$ & $53.16^{\mathrm{a}} \pm 6.9$ \\
\hline$P$-value & 0.0001 & 0.0001 & 0.0001 & 0.002 & 0.008 \\
\hline
\end{tabular}

Means with different letters $(A, B$ and $C$ or $a, b, c)$ in the same column are significantly different at $(P<0.05)$. 
On the other hand, treating does with $\mathrm{Cr}$ throughout postpartum period did not reveal any enhancement in $\mathrm{E}_{2}-17 \beta$ levels neither in hot nor mild climates. However, Se-E injection showed significant enhancement in $E_{2}-17 \beta$ during days of postpartum with the highest mean value of $58.23 \mathrm{pg} / \mathrm{ml}$ on day15 postpartum. Inspection data of climate and treatment interactions, the increase of $E_{2}-17 \beta$ due to Se-E on $15^{\text {th }}, 30^{\text {th }}$ and $45^{\text {th }}$ days of PP was observed only under mild climate conditions (Table 3).

\section{DISCUSSION}

\section{Effect of climate conditions and treatments on progesterone levels.}

Dietary use of a chromium supplementation for approximately 2 months in peak and early lactation cows under natural high ambient temperatures had no effect on progesterone levels (Nikkhah et al. (2011). In this respect, the present $\mathrm{Cr}$ results of estrous cycle and pregnancy under hot conditions are in agreement with those of Nikkhah et al. (2011) but not with results of postpartum since it was almost lower in progesterone than control. The obtained postpartum results agreed with the findings of Yang et al. (1996) who found that progesterone levels did not differ in Cr-supplemented cows from control postpartum cows at week 2 , while progesterone level at postpartum week 6 was significantly lower in treated cows than control with value about $2.57 v s .3 .34 \mathrm{ng} /$ $\mathrm{ml}$, respectively. Furthermore, Burton et al. (1995) found no significant effect of $\mathrm{Cr}$ supplementation on $\mathrm{p} 4$ at weeks $-1,0,1$ and 2 post calving, although $\mathrm{Cr}$ supplemented cows tended to have lower P4 concentrations that declined more rapidly post calving than control cows. On the other side, Ganie et al. (2014) stated that supplementation of Se (0.2 ppm Se selenite) had no effect $(\mathrm{P}<0.05)$ on serum $\mathrm{P} 4$ profile in buffalo heifers during estrous cycle compared with control group. The present results agreed with the later authors during estrous cycle at hot and mild season (Table2).
In pregnant Baladi goats observed that Se-E increased serum P4 during early, mid- and latepregnancy (Esa, 2011 and Habeeb et al.,2012). In the same trend, plasma P4 concentration increased during pregnancy, reaching its highest level at 19$20^{\text {th }}$ weeks and then declined during the last 2 weeks before parturition (Krajnicakova et al., 2003). In addition, Kamada et al. (2014) in pregnant heifers found that Se supplementation $(0.3 \mathrm{ppm}$ sodium selenite) increased plasma P4 in the 29-39 weeks of pregnancy from 4.98 to $6.86 \mathrm{ng} / \mathrm{ml}$, on average. The authors suggested that Se contributes to maintaining the function of the corpus luteum and/or placenta in the latter period of pregnancy. Postpartum results clearly showed highly significant increase in $\mathrm{P} 4$ concentration at $30^{\text {th }}$ day postpartum due to Se-E injection especially under hot climate conditions. These are in the same trend of khan et al. (2015) in buffalo. The authors estimated progesterone from 30 days postpartum to evaluate the effect of vitamin $E$ and mineral supplementation on the initiation of cyclicity in the experimental buffaloes, Se-E group showed early initiation of cyclicity (32 days postpartum) compared with control group (35 days postpartum). Cyclicity in most of the animals might have been initiated earlier than 30 days as was evident from P4 concentration. Mavi et al. (2006) found that supplementation of vitamin $\mathrm{E}$ and selenium to Murrah buffaloes during pre-partum period resulted in early initiation of postpartum ovarian activity and early exhibition of first postpartum heat, as well as, duration of first $\mathrm{P} 4$ rise of over $1 \mathrm{ng} / \mathrm{ml}$ of plasma was found to be significantly longer in Se-E supplemented buffaloes.

\section{Effect of climate conditions and treatments on estradiol-17ß levels.}

Feed supplementation with $0.25,0.5$ and $1.0 \mathrm{mg}$ $\mathrm{Cr} \mathrm{kg}{ }^{-1}$ dry matter, respectively, significantly developed graffian follicles and estrus incidence of dairy heifers (Biswas et al., 2006). In this respect, the cur- 
rent increase of estradiol-17 $\beta$ throughout estrous cycle due to $\mathrm{Cr}$ goes in harmony with those of Biswas et al. (2006) .This increase in $\mathrm{E}_{2}$ concentrations during estrus may reflect $\mathrm{Cr}$ enhancing effect on graffian follicles growth and maturation and subsequently released amount of estradiol-17 $\beta$ from granulose cells. In addition, it may be due to minimization of the early atresia of medium sized follicles caused by heat stress (Roth et al.,2000) and this may attribute the obtained increase of $\mathrm{E}_{2}(\mathrm{P}<0.05)$ at luteal phase under hot season condition.

It is known that heat stress reduces plasma concentrations of E2 and lower follicular E2 concentration, aromatase activity, LH receptor level, and delay ovulation (Ozawa et al., 2005). Some effects of heat stress may involve adrenocorticotropic hormone (ACTH) and increase cortisol secretion. ACTH has been reported to block E2 induced sexual behavior (Habeeb et al., 2012 and Hein and Allrich, 1992). Increased corticosteroid secretion has been suggested, because this can inhibit GnRH and thus LH secretion (Gilad et al., 1993). Many studies confirmed the decrease of cortisol due to $\mathrm{Cr}$ administration, which in turn may act on alleviate the adverse effects of heat stress on reproductive hormones (Pechova et al.,2002, Louise, 2003 and Soltan et al., 2012).

$\mathrm{Cr}$ exerts a significant influence on follicular maturation and luteinizing hormone. Postpartum results indicated that $\mathrm{Cr}$ supplementation had no effect on enhancing estradiol-17ß levels during postpartum period neither under mild nor hot season conditions (Tuormaa, 2000). These results are in agreement with those of Burton et al. (1995) who found no significant effect of Cr supplementation on estradiol on weeks $-1,0,1$ and 2 post calving. On the other side, Se-E increased $\mathrm{E}_{2}$ concentrations during estrus and postpartum period not only under mild conditions but also under hot season. Administration of $0.5-1.5 \mathrm{mg} / \mathrm{ml}$ selenium and 50 $\mathrm{mg}$ vitamin $\mathrm{E}$ provides a real strong influence to the increased concentrations of estrogen $\left(\mathrm{E}_{2}\right)$ during estrus in dairy cows compared with control group ( 9.9 vs. 7.81 $\mathrm{pg} / \mathrm{ml}$, respectively) (Prasdini, et al., 2014). The supplementation of vitamin E-selenium to repeat breeder and anoestrous buffaloes relieved the oxidative stress as shown by the reduced levels of lipid peroxidation, activities of superoxide dismutase and glucose-6-phospahate dehydrogenase along with increased vitamin $E$ and $\beta$-carotene and improved blood biochemical composition in vitamin E-Se supplemented animals (Nayyar and Jindal, 2010).

In conclusion, $\mathrm{Cr}$ showed slight increment in E2$17 \beta$ concentrations at estrous but not in postpartum period, however it enhanced $(\mathrm{P}<0.05) \mathrm{P} 4$ levels during different stages of goats reproductive cycle. Se-E increased $(\mathrm{P}<0.05) \mathrm{E} 2$ levels at estrous, pregnancy and PP periods especially under mild climate conditions, the same trend was obtained for $\mathrm{P} 4$ concentrations, except postpartum period.

\section{REFERENCES}

- Al-Katanani, Y. M.; Paula-Lopes, F.F. and Hansen, P.J. (2002): Effect of season and exposure to heat stress on oocyte competence in Holstein cows. J. Dairy Sci., 85: 390 .

- Biswas, P.; Haldar, S.; Pakhira, M.C.; Ghosh, T.K. and Biswas, C. (2006): Efficiency of nutrient utilization and reproductive performance of pre-pubertal anestrous dairy heifers supplemented with inorganic and organic chromium compounds. J. Sci. Food Agric., 86:804

- Bonomi, A.; Quarantelli, A.; Bonomi, B. M. and Orlandi, A. (1997): The effects of organic chromium on the productive and reproductive efficiency of dairy cattle (in Italy). Rivista di Scienza dell'Alimentazione, 26: 21.

- Buchanan-Smith, J.G.; Nelson, E.C. and Tillman, A.D. (1969): Effect of vitamin $E$ and selenium deficiencies on lysosomal and cytoplasmic enzymes in sheep tissues. J. Nutr., 99:387.

- Burton, J.L.; Nonnecke, B.J.; Elsasser, T.H.; Mallard, 
B.A.; Yang, W.Z and Mowat, D.N. (1995): Immunomodulatory activity of blood serum from chromiumsupplemented periparturient dairy cows. Vet. Immunol. Immunopathol., 49(1-2): 29 .

- $\quad$ Chemineau, P.; Baril, G.; Leboeuf, B., Maurel, M.C.; Roy, F.; Pellicer-Rubio, M.; Malpaux, B. and Cognie, Y. (1999): Implications des progres recents en Physiologie de la reproduction dans l'espece caprine. INRA Prod Anim. $12: 135$

- Duncan, D. B. (1955): Multiple range and multiple Ftest. Biometrics, 11: 1 .

- El-Tarabany, M. S.; El-Tarabany, A.A. and Atta, M. A. (2018): Effect of season on hormonal profile and some biochemical parameters at different stages of estrous cycles in Baladi goats, Biological Rhythm Research, DOI: 10.1080/09291016.2018.1440775.

- El-Tarabany, M. S; El-Tarabany, A.A. and Atta, M.A. (2017): Physiological and lactation responses of Egyptian dairy Baladi goats to natural thermal stress under subtropical environmental conditions. Int. J. Biometeorol., 61: 61 .

- Elvinger, F.; Natzke, R.P. and Hansen, P.J. (1992): Interactions of heat stress and bovine somatotropin affecting physiology and immunology of lactating cows. J. Dairy Sci., 75: 449.

- Emesih, G.C.; Newton, G.R. and Weise, D.W. (1995): Effect of heat stress and oxytocin on plasma concentration of progesterone and 13, 14 dihydro15-keptoprostaglandin F2 $\square$ in goats. Small Ruminant Research, 16: 133.

- $\quad$ Esa, R.A. (2011): Effect of vitamin E and selenium supplementation on reproductive efficiency and immune response of Baladi goats under Southern Sinai. Ph.D., thesis, Women's Collage for Arts, Science and Education, Ain Shams Univ., Cairo, Egypt.

- $\quad$ Fatet, A.; Maria-Teresa, P. and Leboeu, B. (2011): Reproductive cycle of goats. Anim. Repr. Sci., 124: 211.
- Ganie, A.A.; Baghel, R.P.; Mudgal, V.; Aarif, O. and Sheikh, G.G. (2014): Effect of selenium supplementation on reproductive performance and hormonal profile in buffalo heifers. Indian J. Anim. Res., 48 (1): 27.

- Gilad, E.; Meidan, R.; Berman, A.; Graber, Y. and Wolfenson, D. (1993): Effect of heat stress on tonic and GnRH-induced gonadotrophin secretion in relation to concentration of oestradiol in plasma of cyclic cows. J. Reprod. Fertil., 99: 315.

- Hansen, J.P. (2009): Effects of heat stress on mammalian reproduction. Phil.Trans. R. Soc. B., 364: 334.

- Hein, K.G. and Allrich, R.D. (1992): Influence of exogenous adrenocorticotropic hormone on estrous behavior in cattle. J. Anim. Sci., 70:243.

- Jordan, E.R. (2003): Effects of heat stress on reproduction. J. Dairy Sci., 86: (Suppl. E): 104.

- Habeeb, A.A.M; Teama, F.E.I. and EL-Tarabany, A.A. (2012): Effect of adding selenium and vita$\min \mathrm{E}$ to the diet on reproductive traits of female zaraibi goats and growth of their kids. Isotope. \& Rad. Res., 44(3): 693.

- Kamada, H.; Nonaka, I.; Takenouchi, N. and Amari, M. (2014): Effects of selenium supplementation on plasma progesterone concentrations in pregnant heifers. Anim. Sci. J., 85(3): 241.

- Khan, H.M.; Mohanty, T.K.; Bhakat, M.; Gupta, A.K.; Tyagi, A.K. and Mondal, G. (2015): Effect of vitamin-E and mineral supplementation on biochemical profile and reproductive performance of buffaloes. Buffalo Bulletin, 34(1):63.

- Krajnicakova, M.; Kovac, G.; Kostecky, M.; Valocky, I.; Maracek, I.; Sutiakova, I. and Lenhardt, L. (2003): Selected clinical- biochemical parameters in the puerperal period of goats. Bulletin of Veterinary Institute Pulawy, 47: 177

- Louise, N., (2003): Postpartum changes in hormones and metabolites during early lactation in summer and winter calving Holstein cows. MS Thesis, Department 
of Animal Science, Graduate Faculty of North Carolina State University, Raleigh, NC, USA.

- Marai, I.F.M.; Bahgat, L.B.; Shalaby, T.H. and Abdel-Hafez, M.A. (2000):Fattening performance, some behavioral traits and physiological reactions of male lambs fed concentrates mixture alone with or without natural clay, under hot summer of Egypt. Ann. Arid Zone, 39 (4): 449.

- Mavi, P. S.; Pangaonkar, G. R. and Sharma, R. K. (2006): Effect of vitamin $E$ and selenium on postpartum reproductive performance of buffaloes. Indian J. Anim. Sci., 76(4): 308 .

- Nayyar, S. and Jindal, R. (2010): Essentiality of antioxidant vitamins for ruminants in relation to stress and reproduction. Iran. J. Vet. Res., 11(1): 1.

- Nikkhah, A.; Mirzaei, M.; Khorvash, M.; Rahmani, H. R. and Ghorbani, G. R. (2011): Chromium improves production and alters metabolism of early lactation cows in summer. J. Anim. Physiol. Ann., 95:81.

- NRC, (2007): Nutrient Requirements of Small Ruminants: Sheep, Goats, Cervids, and New World Camelids. Washington, DC, Natl. Acad. Press.

- Ozawa, M.; Tabayashi, D.; Latief, T. A.; Shimizu, T.; Oshima, I. and Kanai, Y. (2005): Alterations in follicular dynamics and steroidogenic abilities induced by heat stress during follicular recruitment in goats. Reproduction, 129: 621 .

- Pechova, A. and Pavlata, L. (2007): Chromium as an essential nutrient: a review. Veterinarini Medic., 52(1): 1 .

- Pechova, A.; Cech S.; Pavlata L. and Podhorsky A. (2003): The influence of chromium supplementation on metabolism, performance and reproduction of dairy cows in a herd with increased occurrence of ketosis. Czech J. Anim. Sci., 48: 348.

- Pechova, A.; Pavlata, L. and Illek, J. (2002): Metabolic effects of chromium administration to dairy cows in the period of stress. Czech J. of Anim. Sci., 47: 1 .

- Prasdini, W. A; Rahayu, S. and Djati, M. S. (2014): Level of estrogen and cervical mucus $\mathrm{pII}$ as indicator of estrus after calving towards the provision of selenium vitamin $\mathrm{E}$ on dairy cow Frisien Holstein (FII). Int. J. Chem. Tech. Res., 7(1): 190.

- Roth, Z.; Meidan, R.; Braw-Tal, R. and Wolfenson, D. (2000): Immediate and delayed effects of heat stress on follicular development and its association with plasma FSI I and inhibin concentration in cows. J. Reprod. Fertil., 120: 83 .

- Sartori, R.; Sartor-Bergfelt, R.; Mertens, S.A.; Guenther, J.N.; Parrish, J.J. and Wiltbank, M.C. (2002): Fertilization and early embryonic development in heifers and lactating cows in summer and lactating and dry cows in winter. J. Dairy Sci., 85: 2803.

- SAS (1998): Statistical analysis system user's guide, Release 6.0 ed. $4^{\text {th }}$ ed, SAS Institute Inc. Cary, NC, USA.

- Soltan, M. A.; Almujalli, A.M.; Mandour, M.A. and El-Shinway, A.M. (2012): Effect of dietary chromium supplementation on growth performance, rumen fermentation characteristics and some blood serum units of fattening dairy calves under heat stress. Pakistan J. Nutr., 11(9): 751.

- Surai, P.F. (2006): Selenium in Nutrition and Health. $1^{\text {st }}$ ed. Nottingham: Nottingham Univ. Press.

- Tuormaa, T. E. (2000): Chromium selenium copper and other trace minerals in health and reproduction. $J$. Orthomol. Med., 15: 145.

- Williams, J. E.; Myers, J.L.; Richard, C.R. and Grebing, S.E. (1994): Influence of yeast culture, chromium, and thermal challenge on $\mathrm{N}$ and mineral balance in lambs. J. Anim. Sci., 72(Suppl. 2): 86.

- Wise, M.E.; Armstrong, D.V.; Huber, J.T.; Hunter, R. and Wiersma, F. (1988): Hormonal alterations in the lactating dairy cow in response to thermal stress. J. Dairy Sci., 
Effect of Chromium and Selenium-E on Progesterone and Estradiol-17ß Levels during Reproductive Cycle of Baladi Female Goats under Egyptian Conditions ( 57 )

$71: 2480$.

- Yang, W.Z.; Mowat, D.N.; Subiyatno, A. and Liptrap, R.M. (1996): Effects of chromium supplementation on early lactation performance of Holstein cows.

Can. J. Anim. sci., 6: 221. 
مح

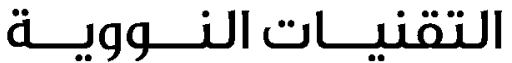 \\ فى العلوم التطبيقية
}

مجلد 6، عدد 1 ، ص 47 : 58، (2018)

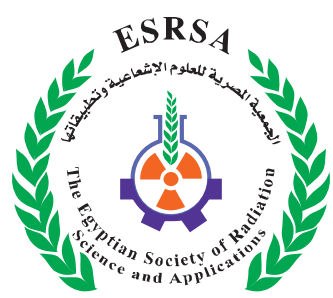

\section{تأثير الكروميوم والسيلينيوم_هـ علي مستويات البروجستيرون والإستراديول__اييتا

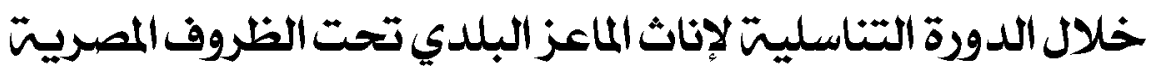

\author{
عبدالكريم إبراهيم محمد السيد' ، حسن أحمد فرغلي'، حسين مصطفي الظاهر' وشريف يوسف عيد'
}

إجريت هذه التجربت لدراستة تأثير معاملتة اناث الماعز المحليت بالكروميوم والسيلينيوم-هـ علي مستويات

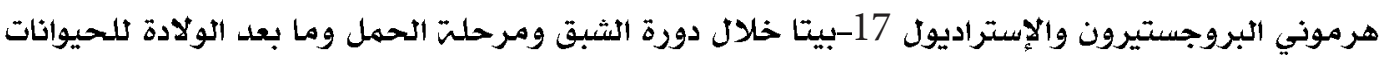

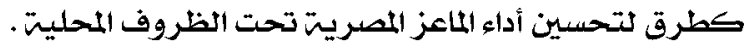

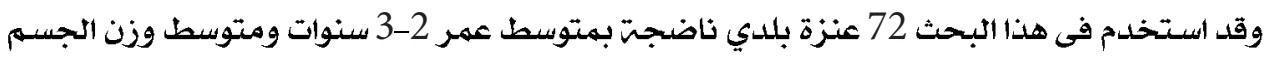

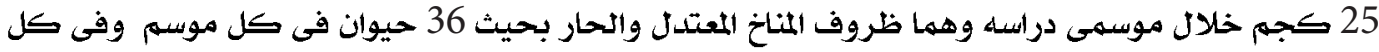

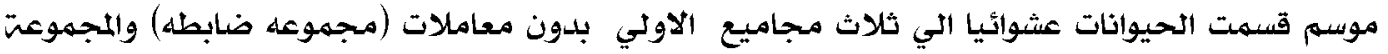

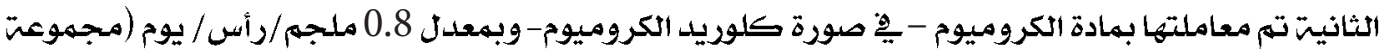

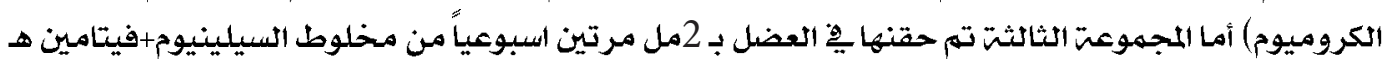

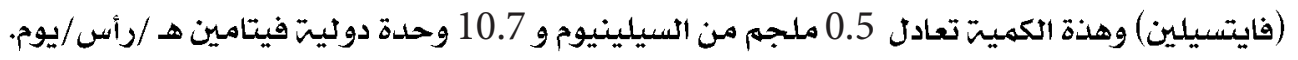

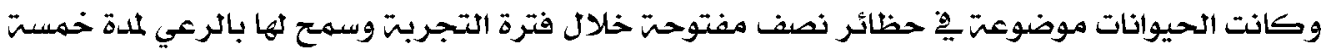

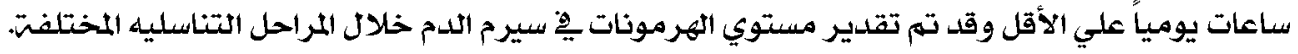
وقد أوضحت النتائج أن مايلى:

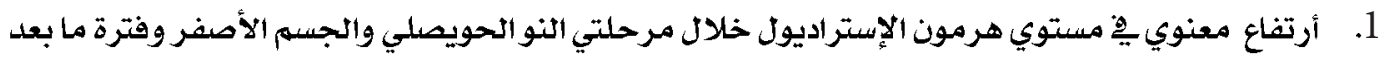

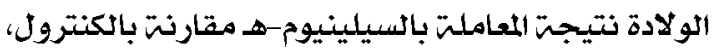
2. كانت مستويات الهرمون أعلي تحت ظروف الجو المعتدل عن الموسم الحار داخل نفس المجمهوعت خلالال معظم المراحل التناسليت المختلفتر.

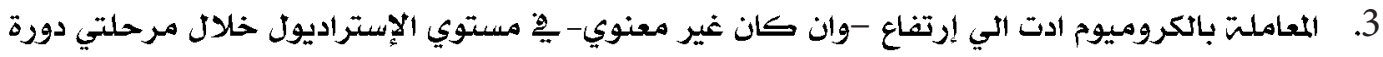

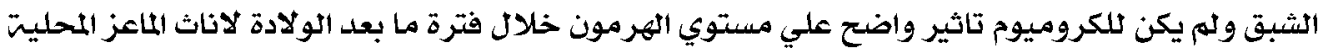
تحت ظروف المناخ المعتدل او الحمار.

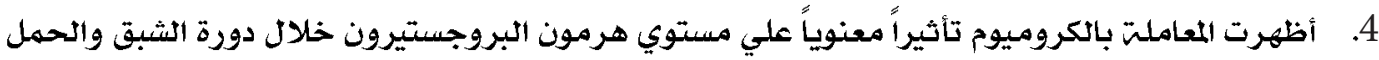

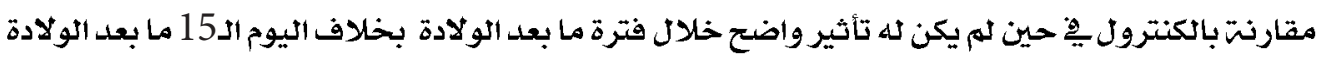

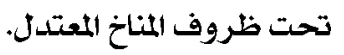

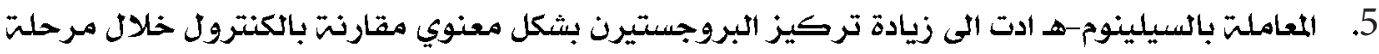

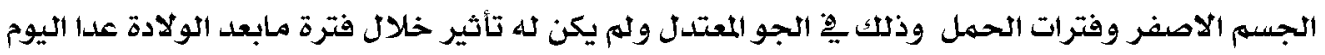
الـ30 تحت ظروف الجو الحار. 